\title{
Nevoid Basal Cell Carcinoma Syndrome
}

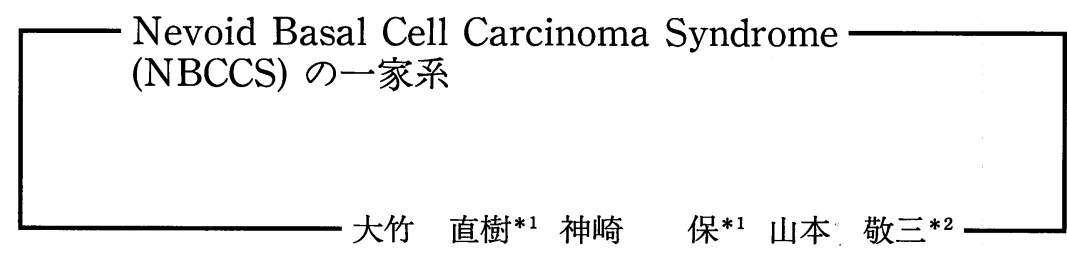

Summary

症例 $1 ： 5$ 歳，女性。生下時から小黒子様皮疹を多数認める。生検により基底細胞上皮 腫 (BCE) と確認。下顎は突出し, 掌蹠に小陥凹あり, 右第五指に生下時からの内反あり。 症例 $2 ： 34$ 歳, 女性。症例 1 の母。幼少時から全身に黒子様皮疹が多発。顎囊胞手術の既 往あり。10個の皮疹を生検しいずれも BCEであった。なお, 顔は下顎骨が突出し, 掌蹠に は多数の小陥凹があった。以上から NBCC 症候群の一家系と診断。

\section{はじめに}

母斑性基底細胞癌症候群 (nevoid basal cell carcinoma syndrome 以下 NBCCS と略）は， 多発性基底細胞上皮腫，多発性顎囊胞，骨系統 異常, 異所性石灰化, 掌蹠に pits を主徵とする 常染色体優性遺伝性の症候群である。また眼, 中枢神経系や内分泌系の病変を合併する。さら に NBCCS は悪性腫瘍発生の母地となるため, 内臓悪性腫瘍と関係のある遺伝性症候群の一つ にあげられる。

今回我々は，母子に発症した本症候群の一家 系を経験したので報告する。

症例

症例 $1 ：$ Y.T. 5 歳，女性

* 1 : Naoki OTAKE, Tamotsu KANZAKI 名古屋 市立大学衹膚科学教室

$* 2$ : Keizou YAMAMOTO 名古屋第二日本赤十字 病院皮膚科
初 診：1990年11月 1 日

主 訴: 全身に多発する無症候性黒色丘疹。

既往歴：特記すべきことはない。

現病歴：生後まもなく全身に径 $1 \mathrm{~mm}$ 大ま での黒色丘疹が多数認められ，数，大きさとも に増してきたため当科を受診した。

現 症：鼻根部の開大, 両下顎の突出した, やや特異な顔貌を呈した。顔面には右眼下部に pyogenic granuloma を認める他は特記すべき 皮疹は認めなかった(図 1 )。体幹には, 約 $2 \mathrm{~mm}$ 大までの黒色丘疹が散在性に多発していた（図 2 )。膝窩部には, 約 $4 \mathrm{~mm}$ 大のやや大きめの黒 色丘疹が散在していた(図 3)。これらはいずれ も黒子または小さな母斑細胞母斑様に見えた。 手掌足底には径 $1 \mathrm{~mm}$ 大の pits が多数存在し た(図 4 )。右第五指に生来からの内反を認めた (図 5 )。

$\mathbf{X}$ 線所見：右第五指内反以外は骨 $\mathrm{X}$ 線上，特 に異常を認めなかった。

組織所見：体幹から 5 力所, 様々な色, 形を した皮疹を生検した。全検体ともメラニンの増 加とともに表皮に連なる形で基底細胞類似の 


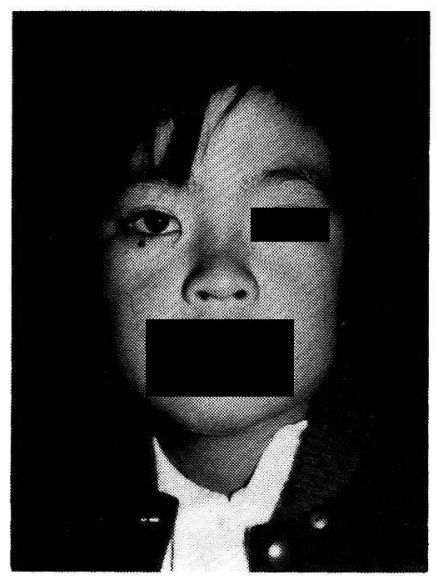

図 1. 症例 1 の顔貌

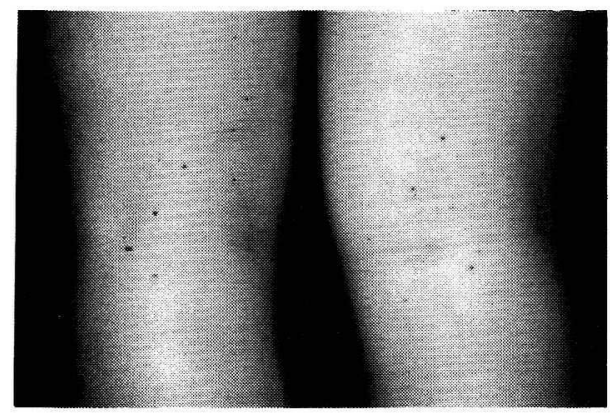

図 3. 症例 1 の臨床像

膝窩部に散在性に多発するやや大きめの黑色丘疹

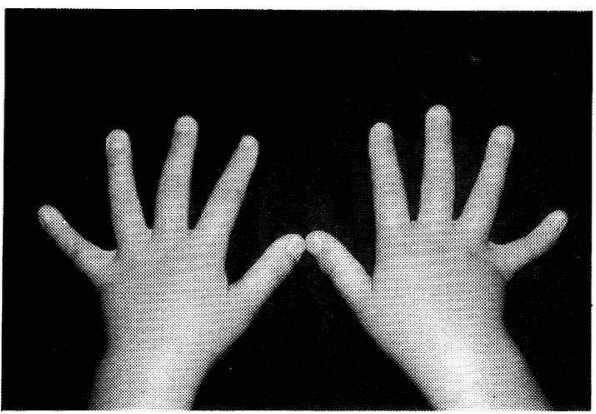

図 5. 症例 1 の臨床像

生来から認める右第五指の内反

N/C 比大の細胞が増生し basal cell epitheliomaの像を呈していた（図6）。

治 療：各々の皮疹は $1 \mathrm{~mm}$ 以下のものが 多く，大きくても $4 \mathrm{~mm}$ 大までであること，年 少の女性であること, また母親(症例 2 ) の BCC のいくつかは自然消退したという既往歴などを

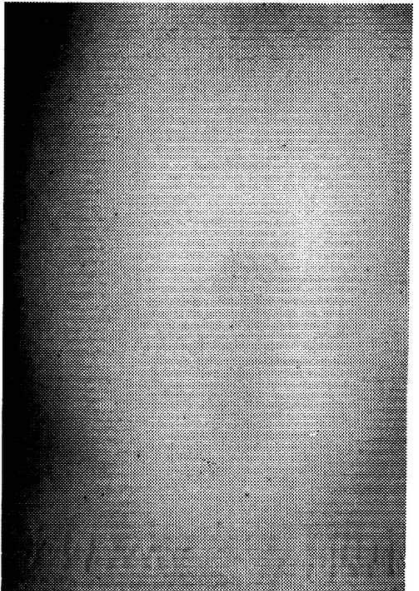

図 2.症例 1 の臨床像 体幹部に散在性に多発する黒色丘疹

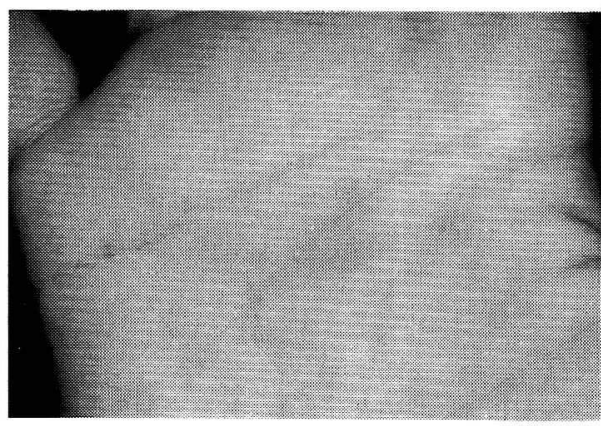

図 4. 症例 1 の臨床像 手掌の pits

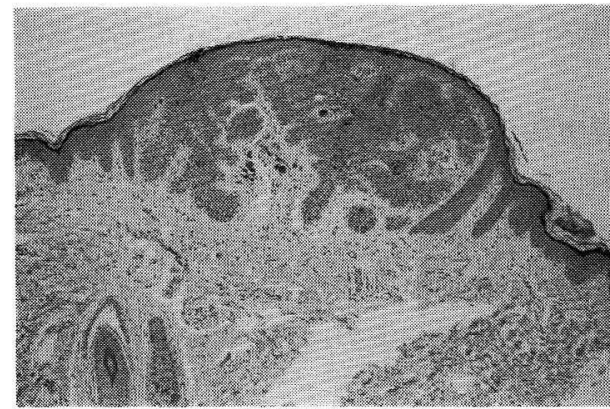

図 6. 組織像 HE 染色

図 2 に見られる黒色丘疹の一つからとったもの

考慮し経過観察にとどめている。

症例 2 : R. T. 34歳, 女性

初 診：1990年11月 1 日

主 訴：全身に多発する無症候性黒色丘疹。

家族歴：症例 1 の母。その他の血族に同様の 多発する黒色丘疹を呈した者はいない（図７）。 


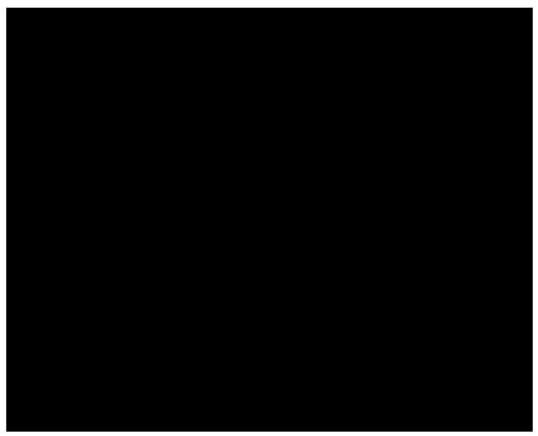

図 7. 家系図

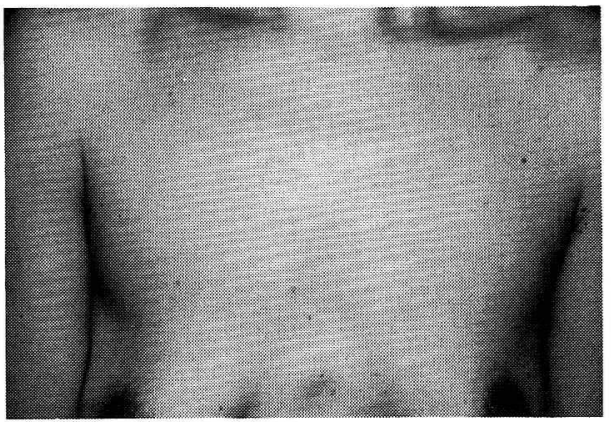

図9.症例 2 の臨床像 胸部に認められる散在性に多発する丘疹

既往歴：18歳時両下顎囊胞摘出。29歳時右鼻 翼 BCC 摘出。放射線照射歴なし。砒素摂取歴な L。

現病歴：幼少時からほぼ全身に径 1 〜 $2 \mathrm{~mm}$ の黒色丘疹が散在性に多発していた。当人の記 憶では黒色丘疹のいくつかは自然消退していっ たとのことである。1989年秋から一部の皮疹が めだって大きくなるのに気づいた。次女が当科 を初診した際に付き添って来院し同時に初診と なった。

現 症: 鼻根部の開大, 画下顎の突出, 両眼 開離を認める特異な顔貌を呈した。顔面には多 発する黒色丘疹が認められ, 右鼻翼には $\mathrm{BCC}$ 摘出後の㓔痕が認められた(図 8 )。前胸部には $1 \mathrm{~mm}$ 以下の淡褐色の丘疹から $5 \mathrm{~mm}$ 大の黒 色丘疹まで様々な色, 形をした皮疹を多数認め た（図 9 )。背部には径 $1 \mathrm{~cm}$ 大の黒色病変を認

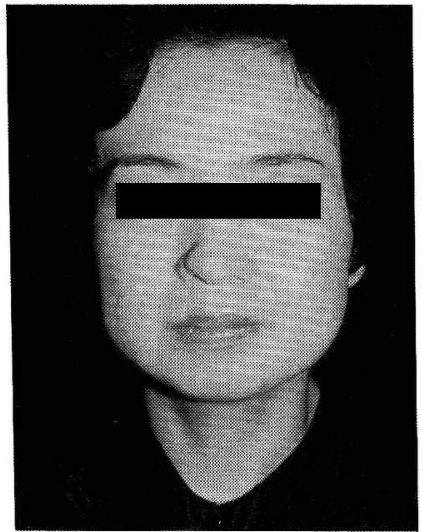

図 8. 症例 2 の顔貌

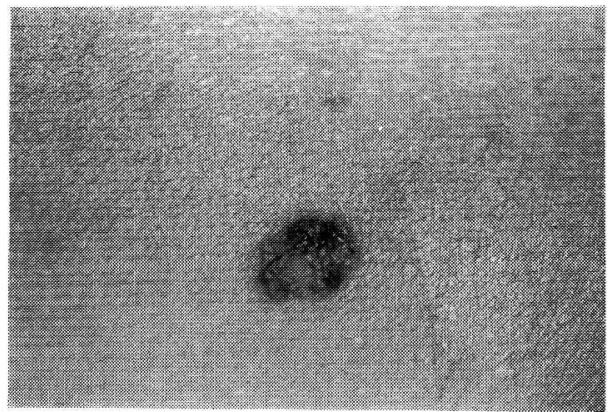

図10. 症例 2 の臨床像

背部に認められる径 $1 \mathrm{~cm}$ 大の黒色病変

め典型的な BCC の臨床像を呈した（図10）。手 掌足底には, 約 $1 \mathrm{~mm}$ 大の pits を散在性に認め た（図11, 12, 13)。

臨床検査所見：血液一般, 血液生化学検査に は異常を認めない。全身骨 $\mathrm{X}$ 線検査上, 摘出済 みの下顎囊胞の既往を除いて, 特記すべき異常 は認めなかった。

組織所見：体幹から 3 力所，外見上異なった 皮疹を生検した。背部の径 $1 \mathrm{~cm}$ 大の黒色病変 では，やや大型，濃染する紡錘形の核を有し $\mathrm{N} / \mathrm{C}$ 比大, メラニンも増加し, 底部では栅状配 列を示した(図14)。胸部に多発する淡褐色の小 丘疹では basal cell 様の細胞が rete ridge の先 端に cell nestを形成し，隣りあったnestが癒 合している像を認める（図15）。以上から BCC と診断した。

治 療：(1)切除，(2)液体窒素凍結療法，(3)電 


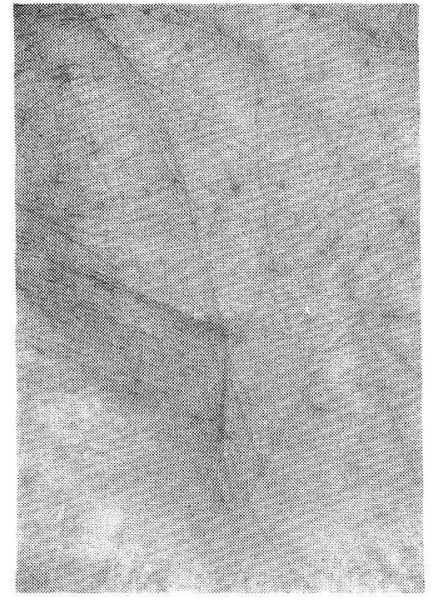

図11. 症例 2 の臨床像 手掌の pits

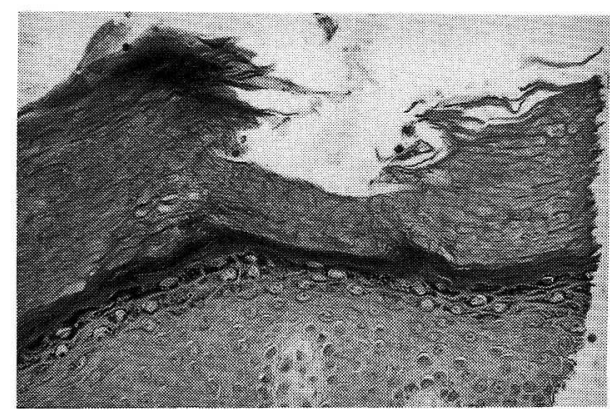

図13. 手掌 pits の組織像 HE 染色 角層の部分欠損を認める

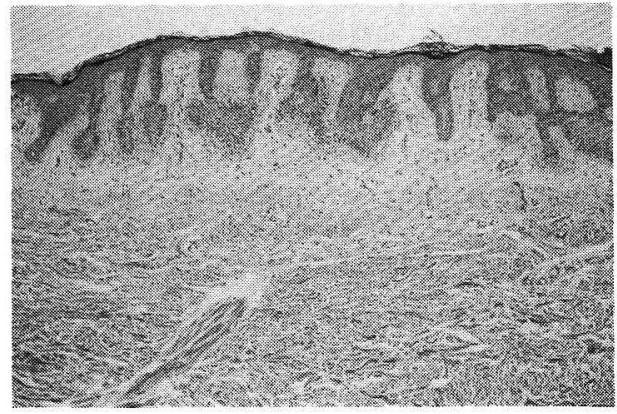

図15. 図 9 の淡褐色小丘疹の組織像 HE 染色

気凝固と搔爬を組合わせた方法の三種類を試み た。その治療効果を判定するため，(2)および(3) の治療の $2 \sim 3$ 力月後に, 各々 3 力所から生検 した。その結果(3)では 3 力所全て完全に治療さ れていたが, (2)では 3 カ所のうち 1 力所の生検 で，真皮内に小さな $\mathrm{BCC}$ の腫瘍塊が残されて

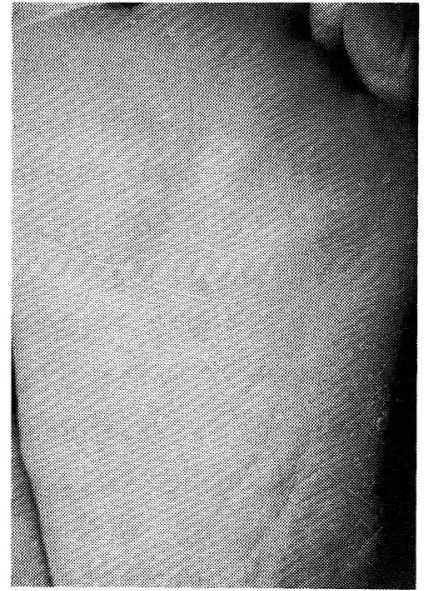

図12. 症例 2 の臨床像 足底の pits

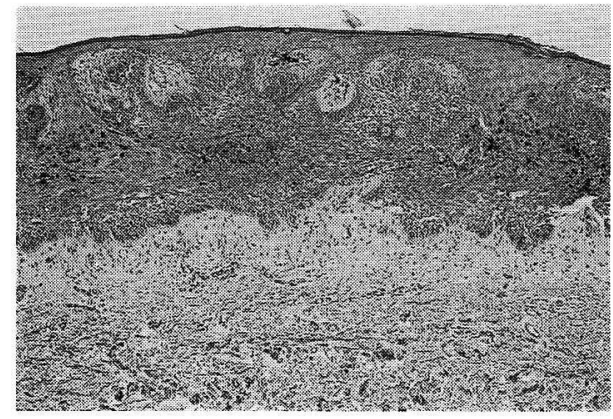

図14. 図10の組織像 HE 染色

いた。

\section{考察}

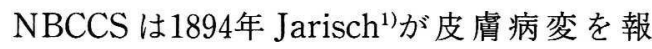
告したのが最初と言われている。1960年 Gorlin $ら^{2)}$ は自験例, 文献例を整理し, 顎囊胞, 多発性 基底細胞上皮腫，骨格系の異常を合併する症例 を症候群として提唱した。

本症は, 加齢に伴い諸病変を発現してゆくが, 特異的診断法はなく，臨床所見から診断を下し ている。臨床所見として (1)多発性基底細胞上皮 腫, (2)枵䨢胞, (3)掌蹠 pits, (4)両眼開離, 前頭骨 側頭骨突出，下顎骨突出などの形態異常による 特異な顔貌, (5)二分胁骨などの胁骨病変, 側彎 症などの脊柱病変を主とした骨系統異常，(6)脳 
硬膜の石灰化，トルコ鞍の bridging を主とした 中枢神経病変, (7)異所性石灰化, (8)眼病変, (9) 内分泌病変, (10)悪性腫瘍, (11)その他, がある3)。 本症の診断基準には一定のものがなく, Gorlin と Goltz $z^{2)} よ る と$ 基底細胞上皮腫, 顎囊胞 の 2 病変に二分胁骨を併せもつものとし, Rayer ら $^{4)}$ は基底細胞上皮腫と顎囊胞のうちど ちらか一方に大脳鎌の石灰化や掌蹠 pitsを併 せもつものであるとしている。Gundlach ら ${ }^{5}$ は 皮膚病変と多発性顎囊胞が認められるもの, ま たはその一方を欠く場合は，明らかな家族性， あるいは二分肋骨，大脳鎌の石灰化などの骨格 系の異常が認められるものとしている。自験例 2 例では Rayer, Gundlachの診断基準を満た しており NBCCSの一家系と診断した。

本症候群の遺伝形式は常染色体優性遺伝と考 えられており, Repassと $\mathrm{Grau}^{6}$ はその遺伝子 を持つ患者の $95 \%$ が何らかの症状を呈すること を報告しているが，一般に遺伝関係や染色体異 常のみられるものや，そうでないものと一定し ていないようである。異常としては, Happle ら ${ }^{7} の$ 報告では基底細胞上皮腫の細胞より検索 した結果, 染色体に切断をみたとある。本邦で 報告されている家族性発生例の報告では染色体 の異常はみられておらず，自験例では検索して いない。自験例においては母と次女のみが,

NBCCSを発症しておりその他の近親者に同症 の発症をみていない。

治療に関しては (1)切除, (2)液体窒素凍結療 法, (3)電気凝固と搔爬を組合わせた方法の三種 類を試みた。治療後の外見は切除では切除部位 にやや盛り上がった瘷痕を残し液体窒素療法で は，当人が気にしないほどの非常に薄い褐色の 色素沈着を残し, 電気凝固ではやや色の濃い色 素沈着を残した。外見上, 液体窒素療法が患者 にとって一番満足のゆくものであった。治療が 患者に与える苦痛は, 液体窒素療法が他の二つ に比べて一番楽であった。治療効果に関しては, 液体窒素療法では圧抵の強さ, 時間によって完
全に BCCを焼ききれる場合と, 一部真皮に BCCの cell nestを残してしまう場合があり， 再発の問題を残すことになった。電気凝固療法 では完全に治療ができた。患者に与える苦痛, 外見上の問題, 治療効果を総合的に考え，また $1 \mathrm{~mm}$ 以下の小丘疹を含めて推定すると約 1 万個という多数の皮疹が存在し, 一部の皮疹は 自然消退していったという患者の記憶とを考え あわせると, 径 $3 \mathrm{~mm}$ 以上の皮疹に対してやや 強めに液体窒素療法を行う方法がより良いもの と考えた。

基底細胞上皮腫の侵襲性の問題, 今後発症す る可能性のある様々の合併症の問題を考之, 自 験二症例についてこれから長期にわたる経過観 察（年に $1 \sim 2$ 回の検診と治療）が必要である と考える。

\section{文献}

1) Jarisch,: Zur Lehre von den Haut Hutgeschwulsten. Arch. Dermatol. Syph. , 28 : 163-222, 1984.

2) Gorlin, R. J., Goltz, R. W.: Multiple nevoid basal cell epithelioma, jaw cyst and bifid rib: Syndrome. New England J. Med. , 262 : 908-912, 1960.

3）新井春枝: 基底細胞上皮腫症候群. 皮膚科 MOOK 母斑・母斑症編. No. 9, 173-180, 1987.

4) Rayer, C. R. W., Towers, J. F., et al.: What is Gorlin's syndrome? The diagnosis and management of basal cell nevus syndrome, based on a study of thirty-seven patients. Brit. J. Plast. Surg. , 30:62-67, 1979.

5) Gundlach, K. K. H., and Kiehn, M. : Multiple basal cell carcinomas and keratocyst - the Gorlin and Goltz syndrome. J. Max. Fac. Surg. , 7: 299-307, 1979.

6) Repass, J.S. and Grau, W. H.: The basal cell nevus syndrome: report of two cases. J. Oral Surg. , 32 : 227-232, 1974.

7) Happle, R., Mehrle, G., et al.: Basalzellnavus Syndrom mit Retinopathia pigmentosa, rezidivieren der Glaskörperblutung und Chromosomen veränderungen. Arch. Dermatol. Forsch. , 241: 96-114, 1971. 